\title{
Women Prisoners and the Drive for Desistance: Capital and Responsibilisation as a Barrier to Change
}

\begin{abstract}
:
There is a significant and growing volume of research into the way in which offenders desist from crime, their resettlement and re-entry into society following a custodial sentence. As is too often the case in criminological research, women are underrepresented in these areas of investigation. This research aimed to investigate how women in the last three months of a prison sentence plan and prepare for their release. Using data generated from qualitative interviews with women prisoners and prison staff over a 13 month period in a closed women's prison in England, this paper will argue that women prisoners have motivation and desire to desist from crime post release but their attempts to plan for release are hindered by a responsibilisation discourse that runs throughout the institution and by a severe lack in all forms of capital (social, cultural, economic and symbolic). This not only results in many women being released with little support in place to help them achieve their aims of a crime free life in the future but also highlights the problems with a prison system based on male centred knowledge.
\end{abstract}




\section{INTRODUCTION}

There is a significant and growing volume of research into the way in which offenders desist from crime, their resettlement and re-entry into society following a custodial sentence. As is too often the case in criminological research, women are underrepresented in these areas of investigation, however this is changing with a growing body of work examining the process of re-entry for women offenders following release (Berman, 2005; Arditti and Few, 2006; Herrschaft et al, 2009; Scroggins and Malley, 2010; Holtfreter and Wattanaporn, 2014). Despite this there is currently no UK study on the prison based resettlement practices of women prisoners, examining issues around resettlement prior to release and the relation this has to desistence.

The research aimed to investigate how women prisoners on a three or more year sentence planned and prepared for their release. It was an ethnographic study conducted over a 13 month period in a closed women's prison in England. The prison was classed as a local and training institution and consequently held women on remand, long and short term sentences plus women on a life sentence. The prison had a Substance Misuse Unit, a hospital wing, a semi-open wing and a Mother and Baby Unit however this was not in use at the time of the research. Accommodation was spread over a number of wings and comprised single, shared and dormitory type cells.

The research involved the generation of data through qualitative interviews with prisoners and staff (support staff and prison officers), observations and the gathering of extensive field notes plus obtaining the position of, and working as, a teacher in the prisons education department. Drawing on empirical evidence, this paper will demonstrate that women prisoners have significant motivation and desire to desist from crime post release but their attempts to plan for release are hindered by a responsibilisation discourse that runs throughout the prison and by a severe lack in all forms of capital 
(social, cultural, economic and symbolic). The pre-release experience of women prisoners and prison based resettlement practices appear to be hindering the desistance process resulting in many women being released with little support in place to help them achieve their aims of a crime free life in the future.

While the findings from this research have implications for future desistance, the research is not a desistance study, nor is it an evaluation of whether pre-release programmes, services and experiences are successful in preventing female prisoners re-offending. With this previous work in mind it instead aims to focus on women before they are released rather than after. It is an investigation into women's experiences during the last few months of prison and how what happens in this period could affect and influence the construction of a law abiding and socially accepted life once on the outside. In addition the research examines the perceptions of a variety of staff to obtain their views on the prerelease experience of the women at the prison.

Desistance research highlights an interplay between structural and agentic factors in the road to a crime free life however the focus of much desistance research and resettlement policy has tended towards examining the importance and central role played by agency. For example, the role of selfmotivation, individual interventions and cognitive behavioural therapy (CBT) designed to enhance thinking skills have been at the forefront of policy development (see Palmer et al, 2015). There has been a re-framing in terms of both policy and research focus of structural disadvantage as individual criminogenic needs. This paper will argue that rather than a focus on the role of agency and the resulting drive for individual responsibility, we need to examine and address the structural, gendered barriers that women prisoners face. Women prisoners almost all have one or more mental health conditions (Ministry of Justice, 2013) have numerous issues surrounding motherhood (Caddle and Crisp, 1997) including separation from their children and the problems associated with regaining custody of them after release. They are more likely than men to be victims of domestic violence and sexual abuse (Corston, 2007; Ministry of Justice 2012) and suffer greater levels of economic marginalisation. This research shows that such factors are of key concern and have a significant impact on women's ability to plan for release and their future. Consequently this paper will argue that 
the individualistic drive of much desistance research and policy initiatives serves to maintain and legitimate a system that is not only at best unfair but one that sends women on a trajectory of repeat offending that is difficult to change, fractures families and does little to meet the needs of victims or offenders.

Firstly this paper will provide a brief outline of the literature on women offenders, desistance and reentry. Secondly it will give an overview of the methodology used in this research including an outline of how access was gained and maintained plus information about the conducting of the interviews.

The following section will outline how the use of the concept of capital (Bourdieu 1984, 1986) can be applied to the women prisoner's preparation for release. This section will demonstrate how women prisoner's had significant levels of motivation to change but lacked the capital and ability to engage with the resettlement support services that were on offer. In addition this section will present the prison staff view which was diametrically opposed to the view of the prisoners. Staff believed that the women had no motivation and could access support if they wanted to.

Finally this paper will outline evidence for the existence of a responsibilisation discourse that runs throughout the prison. I will argue how this has placed responsibility for successful resettlement and ultimately desistance squarely with the individual and has led to a move away from the recognition of the importance of gendered structural factors in the reduction of re-offending.

\section{LITERATIRE ON WOMEN, DESISTANCE AND POST RELEASE}

As stated, the findings of this research have implications for women's desistance and it is therefore worth noting that with only a few exceptions, (Graham and Bowling, 1995; Uggin and Kruttschnitt, 1998; Flood-Page et al., 2000; Giordano et al., 2002; Rumgay, 2004; Barry, 2007, 2012; Giordano 2014; Brown and Ross, 2010; Leverentz, 2014) the evidence for the development of the predictors and factors that lead to desistance is drawn from research using male only samples. The discussion of gender differences in this field is therefore comparatively limited. More specifically, the focus of 
studies on re-entry and reintegration following custody have generally tended to be on male offenders or on the general offending population (predominantly men). While studies of the effects of incarceration on families, children and communities invariably involve women, they tend to occupy the role of the person affected by their partners' imprisonment. The focus has less often been on female offenders themselves (Leverentz, 2006). Moore and Scraton (2014) also argue that despite research pointing out the distinct gendered needs of women in prison, they "at best remain marginal to the study and practice of imprisonment" (Moore and Scraton, 2014: 1).

However, this is changing with a number of research projects examining the process of reintegration and resettlement for women offenders. Studies which specifically document women's experience of post-release and which examine issues around resettlement and re-entry (Carlton \& Segrave, 2011, 2013, 2014; Berman, 2005; Arditti and Few, 2006; Herrschaft et al, 2009; Cobbina \& Bender 2012; Baldry 2010; Brown \& Ross 2010; Scroggins \& Malley 2010; Holtfreter and Wattanaporn, 2014; Huebner, De Jong \& Cobbina, 2010) are contributing to the building of a woman-centred literature around the topic of desistance. Such studies attend to women's experiences of recidivism and desistance after experiencing specific types of punishment or penal intervention however there is still work to be done around the gendered differences in desistance. In an attempt to investigate whether male-based theories of desistance apply to women offenders, Roderman et al (2016) reviewed 44 studies of female desistance and where available considered gender differences. Of relevance to this paper, is that gender differences were found in the influence of children and the role of supportive relationships. The picture is complex but Rodermond et al. (2016) point out that men do not benefit as much from family bonds as do females. In terms of children, qualitative work shows that the transition to motherhood is linked with a reduction in offending (Kreager et al., 2010). "Having children and supportive relationships is found to influence female desistance to a considerable extent" (Roderman, 2016: 22). 


\section{RESEARCH METHODS}

The ethnography was conducted over a thirteen month period at a closed women's prison in England. During this time I spent five days a week at the prison conducting interviews, observing the day to day workings of the institution and teaching both within the education department and doing outreach education work with women who had to remain on the wings. Qualitative semi structured interviews (using a digital audio recording device) were conducted with nineteen prisoners and eleven members of staff, both prison officers and support staff and it is data from these interviews that is presented in this paper. In addition extensive notes were compiled throughout the research in the form of a fieldwork diary. This documented day to day observations and experiences, reflections on each of the classes I taught, my initial visits to the prison, training undertaken and thoughts on each interview. The fieldwork diary also enabled me to record my own feelings and emotions about the research experience and to document initial impressions of the prison and how these changed over the year I was there. As stated, alongside the research, I was employed as a sessional teacher in the prison education department and as a result had access to all areas of the prison that a member of nonuniform staff is afforded, including my own set of keys which enabled me to move freely around the institution without relying on staff to escort me. All staff knew I was also a researcher and this dual role was at times tricky to balance. It is worth noting that for 9 months of the fieldwork I was pregnant with my first child which had an impact on the research experience (for a discussion of this see Hart, 2014).

The research sample was women who are 21 years of age and over, British nationals who were in the last three months of a three or more year sentence but excluding those on an indeterminate life sentence.

In regards to this study, the inclusion of foreign national women in the sample was not feasible as these women have a different set of needs and requirements from both the prison system and agencies involved in their resettlement making comparison difficult. All the women interviewed fell within the 21-40 age group. Had women older than 40 met the other requirements in the sample they would not 
have been excluded on the basis of age but during the fieldwork time frame no women over the age of 39 were due for release. In regards to the younger end of the range; women aged under 21 were not included in the sample as they would have spent part of their 3 year sentence in a juvenile unit making comparisons between the women's experiences more difficult. The interviews were undertaken in the last three months of the women's sentence. It was assumed that it would be during this time that both the women and support agencies would be focussed on release in the final months before the end of the custodial element of the sentence. Lifers were not included in the sample due to the indeterminate nature of their sentence. Once those who fell into the research sample were identified using the Local Inmate Database System (LIDS), the location of these individuals was then checked by me to ascertain if it was possible to interview them. For example prisoners who were being held in segregation were not accessible and could not be interviewed. Despite being within the target group, some women were unsuitable for interview for other reasons. For example a prisoner may have been on an elevated risk of suicide or self-harm or have had a mental or physical health condition that made her unable to be interviewed. Generally however women in this position were being held on the hospital wing or in the Substance Misuse Unit (SMU), which showed up on LIDS. All women who fell into the above criteria were invited for interview in the 13 month period and all women who were invited agreed to take part except one. All interviews that were scheduled took place and were completed.

The process of gaining access to the prison itself was a lengthy one and had a number of stages. Firstly official permission had to be sought which was done by completing the application form and providing the relevant supporting literature and documentation. Wahidin points out 'The success of negotiating, gaining and maintaining access involves diplomacy and serendipity where unexpected avenues open up and anticipated obstacles disappear' (Wahidin, 2004: 21). This was indeed the case as my initial application for access to an open women's prison was denied. This was a surprise as I assumed this would be easier for the prison service to accommodate as I would require less monitoring and support from time-limited staff due to the more open nature of the institution. However it was the second application to the preferred closed prison that was successful. This was in 
part due to the offer of teaching in the education department and consequently the lesser amount of supervision I would need therefore not such a burden on staff who were already stretched. A separate application form also had to be completed in order to gain permission from the Probation Service to interview their staff as they were not employed by the Prison Service. This was undertaken once the fieldwork was underway and was successful.

The second stage of negotiating access was with individuals responsible for the running of the prison. I was assigned a contact person and it was from this individual that I learnt the conditions under which my research could go ahead. It was agreed that I would report to my contact each month and provide information about initial findings, how the research was going in general and to discuss any problems I had.

The final stage of negotiating access was with the individuals I wished to interview. Access to the prisoners was gained directly. The prisoners were identified on the LIDS and the live register (register containing basic information and location details of each prisoner produced twice daily) as falling within the target sample group.

Following the identification of a suitable potential respondent, a letter was delivered to the womans cell on the wing. I then undertook a follow up visit in order to answer any queries, obtain her full informed consent and to arrange a date and time for the interview to take place. Staff were contacted in a variety of ways, by email, phone or I would visit their departments in person. Again letters were provided explaining the research.

The interviews with prisoners were conducted in two main locations with a couple of exceptions. The first and most commonly used location was the 'lifers' room' on the wing which housed those on a longer or indeterminate sentence. It was quite a relaxed room with a more homely atmosphere than the rest of the wing. Interviews were rarely disturbed when taking place in this location but there was the general noise of the wing to contend with, for example, announcements over the tannoy and noisy staff and prisoners. The second main location for prisoner interviews was in the women's own rooms on the semi open wing at the prison. Women housed on this wing had keys to their own doors and had 
greater freedom of movement than in other residential areas of the prison. Finally two interviews took place in the main association area on one of the wings. This was due to the lifers' room being booked and on the other occasion the individual was disabled and there was no disabled access to the upper level where the room was located. Background noise and lack of privacy were an issue here as other prisoners were working around us and prison officers did not respect our privacy and failed to keep their distance. Staff interviews were conducted in staff offices and wing offices.

The analysis was conducted using a grounded theory approach (Glaser and Strauss, 1967). Following the completion and transcription of the interviews the decision was taken to apply a consistent form of indexing or coding to the data. Grounded theory coding enables the catagorising of segments of data in order to allow an analytic accounting of them (Charmaz, 2014). A set of codes was developed for both the prisoners and staff interviews, which were similar but not identical. The creation of the codes for both sets of data stemmed from the main research questions and the interview schedules that had been developed from these. The similarity in questions asked to both sets of interviewees and the resulting similar set of codes meant that comparisons between prisoner and staff accounts could be made. Coding was important in order to retrieve examples of particular arguments and themes and to present the evidence in a coherent way. The interview transcripts, due to the nature of the semi structured interview method, were not sequential or ordered and coding meant that sections of the data became more easily accessible. This coded data was not the finished article in terms of analysis. Instead it was a more organised tool with which I could undertake further analysis. For example I may have wanted to compare what prisoners and staff said about the issue of prisoner motivation. The code entitled 'motivation and desire' had been applied to both the prisoner and staff interviews and the content of these pieces of data could then be compared. However, it was not simply comparisons that were made using the coded data. Analysing a particular code and its contents would often direct me to another area, in this instance issues around the way in which prisoners access support services. The coded data, essentially based around the research questions, was used as a starting point that would move the analysis on to another emerging theme or argument to be explored. A grounded theory 
approach like this enables a flexible strategy of going back and forth between data and analysis thus constructing a theory 'grounded' in the data (Charmaz, 2014).

This method of analysis was however by no means perfect. There were some sections of data from the transcriptions that were not possible to code in this way. For example, one prisoner gave a detailed account of being assaulted by a prison officer. This was too complex a section to code in the usual way, as breaking down this account into smaller sections of codes would have lost its impact and the context in which it was given. On this point it is also important to note that it was vital to remember and not dismiss the context in which these accounts were being given. A danger with using this form of coding is that the coded data is being viewed out of context and 'compared with other similarly decontextualised sections of data' (Mason, 2002: 158-9). It is from this process of moving backwards and forwards between the research questions and the data that the codes were created and applied and through this themes and arguments developed and emerged.

\section{FINDINGS AND DISCUSSION}

\section{Capital, Aims for the Future and Motivation to Change}

A key finding from this research demonstrates how the women prisoners lack the necessary capital for desistance and how the prison system fails to equip them with the required tools to negotiate what is an increasingly complex resettlement system. In line with the structural, gendered barriers noted in the introduction above, an analysis of the characteristics of this research sample highlight the significant disadvantages faced by the women which manifest in a lack in capital. Mental health concerns, selfharm, substance misuse, abuse histories and family bereavement were common place amongst the sample.

The levels of disadvantage amongst women in prison more widely are startling. It is estimated that 66 per cent of women in prison have dependent children under five years old (Prison Reform Trust, 2010). In addition, one third of women in prison are single parents and the main care giver (Corston, 
2007). One quarter of women in prison have been in Local Authority Care and over half have suffered inter personal violence (Social Exclusion Unit, 2002). Women prisoners have a high likelihood of low educational attainment with nearly 40 per cent having left school before 16 and 10 per cent aged 13 or younger. (SEU, 2002). Around 70 per cent of women entering custody require clinical detoxification and that 65 per cent had used a drug in the year before custody (Cabinet Office Social Exclusion Task Force, 2009). In a national survey of the needs of newly sentenced prisoners, 22 per cent of women were classed as 'heavy drinkers' in the four weeks prior to the commencement of their custodial sentence (Stewart, 2008). Estimates place the proportion of people with mental health conditions in prisons as high as 90 per cent (Roberts and Cobb, 2008). In terms of women, 70 per cent of female prisoners have two or more diagnosed mental health conditions (MoJ, 2013). Suicide is a major concern in women's prisons with 37 per cent of all women sent to prison saying they have, at some point in their life attempted suicide (Corston, 2007).

Despite this; all the prisoners interviewed displayed varying levels of motivation to change, another component research indicates is central to the desistance process (Farrall, 2002; Giordano et al, 2002). Crucially research shows how motivation is something that needs to be tapped into, boosted and nurtured. Giordano et al (2002) focus on the importance of 'hooks for change' or positive influences on the individual in the desistance process. Their research identifies that women are more likely than men to heavily focus on their children as catalysts for change. In this study with women prisoners, more than a third present children and family as their main motivating factor.

'I am motivated by my children and family, when I got found guilty and was sentenced it had a really bad effect on my oldest son, there's been such a lot going on with him. I don't want to let them down again, I really couldn't do that. I want to actually do something with my life, I'm 34 now' (Emma, 34, 5 years).

'Children are my number one priority, I have got others but they are my main priority' (Alima, 32, 4 years) 
Children and family in these cases are a prospective hook for change, providing another element to the prisoners' potential for desistance on release. The desire to spend time with family and rebuild family ties that had broken down due to the women's offending and time in prison is a commonly cited desire. 'I'm 40 this year, and I would really like to spend time with my grandchildren and my girls. I've missed out on a lot with my children and that' (Tracy Ann, 39, 4 years, 4 months). Other qualitative research also highlights the importance of children for women offenders with children being cited by women more often than men in narratives of desistance (Barry, 2010; Giordano et al., 2002)

The data gathered indicates how the women make plans, have long and short term aims for the future and have a desire to go straight. With this in mind, employment and education are also important areas for the women. In virtually every case long-term aims centre round finding employment and/or attending college. Some want further training to continue with on release and to add to skills they learnt in the prison:

'I started my hairdressing before I came in because on my last sentence I did my NVQ Levels 1, 2 and 3 in hairdressing, but just before I came in, because I was obviously on drugs, my sister has got her own hairdressers and she said I can have a job as long as I am off the drugs, so that's what I want to do when I get out' (Anna, 32, 4 years 6 months).

Others express a desire to start their own business.

'Hopefully set up my own business, crafts, making cross-stitch cards and pictures and stuff. My mum taught me how to do cross-stitch. ... Probably start small, a market stall or something once a week, and then word of mouth, through my friends, through the church I will be going to and then go on from there' (Sam, 21, 4 years).

Research highlights that housing and accommodation is a particular problem relating to women being released from prison (MacRae, et al, 2006; Malin, 2004). In line with this, the short-term aims of the 
women in this study are predominantly surrounding housing issues. They have anxiety about where they are going to live and how they will get a house or flat organised as this would, for them, mean that they could start to put other areas of their lives back together

'When I get out I don't want a relationship with anyone, I just want to be on my own, set up a little house up for me and my girls, have my grandchildren at the weekend' (Janice, 38, 4 years 9 months).

For example, it would enable them to claim benefits and for some, begin the process of regaining custody of their children.

'I get out in September and my licence conditions are up in February. I'd like to have my own place by Christmas then I can start to have my kids at weekends, birthdays and Christmas' (Abby, 28, 5 years).

McMahon and Seemungal (2003) stated that despite other motivations, women's concerns on leaving prison were primarily around accommodation and custody issues. Custody of children was an important factor in this research as Alima pointed out 'it's just the kids for me, I just want to get the kids back to me, to be with me' (Alima, 32, 4 years)

There is further evidence in this research of the women's desire and motivation to succeed in establishing a less chaotic life for themselves on the outside. They have had enough of prison and want something different from their life. 'When I look back now I think I've wasted all my life in prison so I am ready to go home and change my life' (Anna, 32, 4 years, 6 months). It is clear from the following accounts that the women recognised the need for motivation in wanting to change their lives or get some help and support from the prison system.

'I kept mithering them asking them to please put me on the list...You then sit back and wait for them to come to you, if I hadn't mithered I don't know if I'd have even done them now. Some girls are waiting a long time. It's quite hard work to get yourself on these things...Jail is what you make of it yourself, you can make it hard, or not, a lot of girls make it hard for 
themselves, I haven't...I think I've been prepared for coming out, obviously I have done it all myself but I feel I have been prepared for it' (Laura, 39, 3 years).

However, it can be argued that simply having motivation is not enough. It is also important to possess the practical skills to achieve results, the capital to negotiate their way through the system and to get some practical support in place.

'To do things like that you have got to help yourself, you've got to have motivation, I have because, as I've been saying before, I am not coming back here...You have got to want to change. I want my kids to see that I am different, for the last 4 years they have seen me as a heroin addict and I can't remember half the things we have done together, and I don't want to be like that. I don't want to be like that with my grandkids, either' (Janice, 38, 4 years, 9 months).

Formulating plans and aims while in a prison cell is not the same thing as having concrete systems of support and practical, tangible strategies in place on the outside. The quotes above show that the lack of this is not due to a deficiency in the women's motivation or a problem with their desire to live a pro social life once released. They have clear aims and plans that they want to action, they have also expressed how motivated they feel and the changes they wish to make. Nor, is it due to an unwillingness to access support services within the prison as many of the staff believe (see below). It is instead due the absence of social, cultural, economic and symbolic capital. The use of capital in relation to an individual's movement out of crime and towards a non-offending lifestyle is not new (Barry, 2007, 2012; Brown and Ross, 2010; Farrall, 2004). The concept has played a central role in desistance research for example, the importance of a good relationship between adult children and their parents has been highlighted as providing additional social capital thus increasing the potential for better adult life course outcomes, including criminal behaviour (Schroeder, et al., 2010). It is worth noting that some of the women interviewed have manage to put plans in place with the help of their family on the outside (social capital), have money saved up from previous employment (economic capital), higher than average educational attainment (cultural capital) or possibly earned 
respect from prison officers and staff (symbolic capital). However, these numbers are small and are the exception rather than the norm.

Interviews conducted with the staff however reveal significant juxtaposition in views. As the above evidence suggests, the women are motivated and all want to desist but instead lack the capital and skills to do so. Conversely staff hold the view that women prisoners do have both access to and the ability to access the resources and support services, but instead lack the motivation to change, desist and build a pro social life on release. 'The ones who do want the help, it's there for them' (Prison Officer- Education). One senior officer comments: 'It's whatever they want to make out of it, because there are things on offer to them' (Prison Officer- Senior).

Staff interpretation is in the most part that significant numbers of prisoners have little interest in desistance and no real desire to change. In addition, the staff assessment of resettlement provision is that the 'help was there if they want it'. This view is in stark contrast to the women prisoners' interviews whose accounts above clearly show levels of motivation to change in their description of their aims on release.

'We have a few prisoners who are really positive and working hard...They want to change, they want to get out of here, get their children back, have a job, but you have got quite a big element as well who don't want that, that really just want to go out and get their next fix, and until they are really ready to change...It is hard' (Prison Officer- Offender Supervisor).

Staff believe that the prisoners should be taking responsibility for their resettlement and for accessing support.

'Quite often it depends on the actual individual and how motivated they are. Some of them are not interested... There is good provision, if the women will engage in it. I think they do have to take some responsibility, they can't expect everything to be done for them. When they are preparing for release they do have to take some responsibility' (Employment Worker). 
The above extract also illustrates the responsibilisation discourse that runs through the prison and seems to form the basis of the overall approach to resettlement provision. This will be discussed further in the following section.

Despite staff claims at support on offer, the overwhelming number of women interviewed feel that they have had little or no help in preparing and planning for their release.

Emily: 'Is there anything the prison has done to help you prepare for your release?'

Susan: 'Nothing...I've been in since January and have still not been told what to do to address my offending behaviour, so I have literally been stuck on the wing swinging a mop around since January and this is me being rehabilitated- I just don't understand' (Susan, 30, 3 years).

"I have had no help or support, it's been like, get on with it and get out and we really don't care what happens to you. It's like they expect you to be back in again anyway" (Lisa, 27, 5 years)

The things a small number of the women have achieved and managed to put in place are individualised, personal successes often against the odds and only where they do possess some degree of social capital, for example getting outside help from family.

'I don't think I've been prepared well enough. I would have liked more support, for more people to actually spend time sitting down and talking to me asking me what help do I want and giving me that help. I have had to do quite a bit of it on my own, it's all been like it or lump it really' (Sam, 21, 4 years).

In addition to feeling they are not given support, all the women report some form of problem when requesting help. This includes applications going missing, unanswered or taking a long time to get a response, verbal requests to officers for referrals and/or information going unanswered plus worrying delays in receiving emergency medical care following self-harming. 
'With this jail you have to go on and on and on at staff before they do anything' (Dawn, 35, 4 years).

'CARATS said they would be there for me and they haven't. I put in 2 or 3 apps 3 months ago and never got any answer at all' (Christine, 39, 3 years)

'When I did this (shows cut to arm) on Sunday night the nurse didn't come out to see it. When the officer contacted her she said give her some dressings and tell her to wait 'til morning. I had to put three dressings on it until it stopped bleeding. At the moment I am anaemic so any cuts I get don't stop bleeding for about 5 minutes' (Abby, 28, 5 years).

In some cases the prison system and on occasion staff, appeared to actually hinder rather than help the planning process, for example Chanice reports being goaded by staff in the run up to release. 'I think it's depressed me more than anything, these are the worst few weeks I have had. I feel as if I have been pushed and pushed to make me explode to the point where they say I can't have a tag, but I've kept it cool' (Chanice, 25, 3 years).

There are a variety of support services available to the prisoners which include Counselling, Assessment, Referral and Throughcare (CARAT), Supporting Others Through Volunteer Action (SOVA), Job Centre Plus, Probation, Together Women and Shelter although this position was vacant throughout the research. Staff claim that all prisoners have to do is 'ask' if they want support however the reality appears to be very different as the processes involved and the barriers women face in accessing this support is far more complex than the prison staff perceive it to be. The requests to meet with staff that are made frequently go unanswered and no women interviewed feel they have any support package in place for their release. These points are discussed further in the following section. So, the women feel they have the motivation to change and want to desist but appear to lack the necessary capital and resources while the staff believe the women have the resources, in the form of support from staff and resettlement services, but lack the motivation to change.

\section{The Responsibilisation Strategy}


In addition to the women prisoners lack in all forms of capital there appears to be a responsibilisation discourse that runs throughout the prison. Garland (2001) points to the transferral of responsibility for crime control from the state to the individual citizen. This new mode of governance he argues is characterized by a responsibilisation strategy where by crime control is shifted from central government to non-state agencies, both private and voluntary and in addition onto individuals.

This responsibilisation strategy has also been applied to female offenders (Hannah-Moffat , 2001). The implementation of the responsibilisation agenda onto female prisoners came from the utilising of the feminist discourse that rejected the notion that female offenders were purely victims of their class or passive sufferers of racial discrimination. It was argued instead that female offenders possessed an agency able to resist and struggle against the oppression to which they were subjected. However, in terms of female prisoners, a progressive feminist approach advocating that oppressed women should and could take control of their own lives became transformed into a call for prisoners to take responsibility for their choices and behaviour. So this 'conceptualisation of shared responsibility emphasizes the responsibilities of the prisoner, the government and the community. Offenders are now seen as being responsible for their own reform' (Hannah-Moffat, 2001: 166).

One example of this transformation is to be seen in the development and implementation of programmes designed to change prisoners 'faulty' thinking and their attitudes towards criminality leading to reductions in re-offending. This responsibilisation of female prisoners ignores the importance of the structural difficulties faced by women on release but paradoxically takes place within the, by definition, controlling and rigid environment of the prison (Hannah-Moffat, 2001). Crucially these new forms of power, while appearing at first glance to distribute power to other 'partners' through the use of rhetoric like 'inclusion' and 'active citizenship', are in fact more extensive and wider forms of social control.

Hannah-Moffat's (2001) work outlined above is based primarily on the Canadian penal system but this responsibilisation strategy can be applied to the UK and appears to be operating in terms of women prisoners and resettlement. Findings from this research identify a responsibilisation discourse 
operating around resettlement provision within the prison and have generated a narrative around women 'helping themselves' which is marketed by not only the prison system but also by both support staff and prison officers. This responsibilisation narrative is ideological and serves to obscure the structural causes of poverty and violence, while absolving governments from responsibility (Sered, 2014) and at the same time placing it firmly at the door of the most vulnerable.

The expectations held by staff on the women, the privileged nature of education provision (based on behavioural 'choices' women make), the focus of cognitive behaviour programmes (on changing women's thinking) and the themes covered on offending behaviour courses all centre around the concept of individual action and responsibility. One prisoner refers to the fact that only those who are well behaved get to attend education in the prison college.

'I was back down to basic [regime] so I was taken off education. Sometimes they [education staff] will come and see you behind your door but that's not the same' (Tricia, 41, 3 years, 6 months).

This is in addition to the overarching prison ethos that the women have to take some responsibility for their resettlement. The majority of staff had a somewhat simplistic analysis of the women's ability and motivation to avoid re-offending: 'The ones who do want the help, it's there for them' (Prison Officer- Education). One senior officer commented: 'It's whatever they want to make out of it, because there are things on offer to them' (Prison Officer- Senior). This idea that 'the help is there if they want it' contributes to the imbedding of the responsibilisation agenda.

There was significant evidence that the staff believed that the prisoner should be taking responsibility for their resettlement and for accessing support.

'Quite often it depends on the actual individual and how motivated they are. Some of them are not interested, they get a form or whatever, and they don't want to fill it in, they say 'you do it for me'; sometimes it's getting them to help themselves, to engage and take the appropriate programmes... There is good provision, if the women will engage in it. I think they do have to take some responsibility, they can't expect everything to be done for them. When they are preparing for release they do have to take some responsibility. We put the 
support there, and there are people who do need the one to one leading by the hand support, and they will get that, but they have got to engage first, it's no good engaging at the last minute. It's quite difficult when we've got the resources we've got within prison, to get everything done there and then for them' (Employment Worker).

This extract illustrates the existence of the responsibilisation discourse that runs through the prison and seems to form the basic approach to resettlement provision. This is problematic for a variety of reasons but not least because this research also found that the women were not explicitly made aware of this requirement. At no point in the prison experience were the women told that they must seek out and engage with support services.

'No one has been to see me, no has told me anything. How am I supposed to know what is going on and what I can do? It happens to a lot of girls in here, just being left.' (Abby, 28, 5 years)

The evidence demonstrates that the women were in fact expecting and waiting for support services to make contact with them before they were released. A constant complaint from the women interviewed was that nobody had been to see them to offer help. 'Nobody has come to see me regarding targets or anything and I've been actively seeking it, but I just seem to get doors shut in my face' (Emma, 33, 5 years). Chanice talks about how she has had to take responsibility:

'Everything I've done, all my courses and everything, I have done myself, I have approached everybody myself, to counsel myself, even my self-harming, not one person has tried to help me during my prison sentence, they've been to see me, said alright then, bye, and I have had to cope on my own. I have told my probation officer all this but I don't think she listens to anything I say. She doesn't credit me for anything...I haven't seen any Benefits people, Housing people; nobody has been to see me' (Chanice, 25, 3 years).

The impact this has on the planning and resettlement process is clear. It becomes very hard for the women to effectively and practically plan for their release without accessing the support services and without indeed knowing that it is their responsibility to do so. The services that are available and the 
system as a whole was something that I as a researcher with the tools and freedom that I had at my disposal, still found complicated to navigate. For the women prisoners it was near impossible.

This research has shown that the women prisoners want to take control of their lives in that they make plans and have aims for the future. Crucially, however, the idea that they all have the agency to make these aims a reality is a fallacy. In truth a small minority of women possess the ability to construct and build a crime free life on release and put concrete plans into place. The majority of the women however need targeted support that recognises the structural inequalities and extreme levels of social exclusion they face. The responsibilisation agenda is preventing the women's engagement with this kind of support. There is a difference then between empowering women to help themselves (through focussed, quality support and wider commitments to tackle social exclusion and inequality) and expecting offenders to take responsibility for their own re-integration, resettlement and desistance.

The responsibilisation strategy has also led to a receding of the recognition of structural, gendered disadvantages that women offenders face, structural issues that in reality are outside the individual control of offenders. Scoular and O’Neill (2007) argue in a similar vein to Cohen (1985), that punishment and welfare can be seen as 'different sides of the same coin' (Scoular and O'Neill, 2007, 770). They state these two processes frame structure and agency in a particular way that leads to individual practices of punishment or support. Kemshall (2002) adds that while structural factors are recognised, they are individualised, as they are used to identify those most at risk and most in need of provision. Structural elements are no longer viewed as inequality, disadvantage and exclusion that are beyond the control of an individual but instead are re-defined as a person's 'criminogenic needs'. The focus is therefore no longer on structural inequalities but instead on individual needs leading to these new forms of governance and control utilising and pushing through the responsibilisation agenda. 'The answer to social exclusion is not structural change but individual re-education, re-training and re-entry into the legitimate economy' (Scoular and O'Neill, 2007, 770-771).

\section{Relationships with staff}


It is also important to examine the day-to-day relationship that prisoners have with officers as this unfortunately appears to be another barrier to the planning process. The overall prisoner view of staff is that there is a few that are willing to try and help but that there are not many the women feel they can approach and talk to. The general opinion of prison officers among the women interviewed is a negative one. It is felt that the majority are seemingly unconcerned with the welfare of the women and that they are unpleasant, insensitive and lack empathy. 'If you want something doing there are certain officers you can ask and they'll go out of their way to do it, then there are other officers who will just basically tell you to do one' (Abby, 28, 5 years). It was noted by some of the women that the staff in this particular prison were harsher than others they had been to.

'The staff here are different to other prisons as well, they are sterner, when I went to [another prison] I was distraught, and the staff were so helpful, it's dead relaxing in there, you feel comfortable in the reception area, it's just a quick pat down and they give you everything in your possession. When I came here, there were a few of us, we were all crying because we'd heard what this prison was like, as soon as you come into reception it's like a boot camp, the staff had such an attitude, and they were taking all our coats off us one by one, because it's illegal to have a coat on with a hood. They make up their own rules' (Chanice, 25, 3 years).

There are also instances where relationships with staff were problematic. It was reported that there was some prejudice from staff against women from the south of England, that those from more local areas would get treated in a more respectful way. Two women had mentioned this as a problem they faced when dealing with officers. 'There are a few officers who are more willing to help people from this area, and I know it's not just me because other people from down South have said the same thing. It's prejudice; really, if it was because we were black there would be uproar' (Emma, 33, 5 years). I had observed similar in relation to my own accent as I had been referred to by one of the officers as the 'new bird who's not from round here'. I was ignored many times when addressing officers on the wing or trying to ask a simple question. While this cannot be entirely put down to regional differences and north south divide tensions, and is largely due to the investigative outsider role which I had, I did find myself modifying my accent and beginning to use colloquial terms in my language to get some of 
the more difficult officers to cooperate. There was also unfortunately a report of serious staff abuse and misconduct by one of the women.

'I've been assaulted by a member of staff in November last year... anyway I said to her I'm going, because you are getting my temper up, and I walked away. As I walked away all I can remember is her throwing me to the floor, and going into a fit and her foot being on my back, that's all I can remember. I've got epilepsy... When I came round I was full of bruises from head to toe, I was naked, she took my clothes off me, threw me in a cell down the block, no knickers on or anything, and it was the time of the month. The room was freezing; all I had around me was a blanket...she got charged. She appealed, but it got knocked back because there was too much evidence against her, they told her she couldn't work in this unit, especially as we have a mother and baby unit... The officer concerned was only here for about 3 months, and apparently, I didn't know this, she hit a girl previously and gave her a black eye' (Abby, 28, 5 years).

It is also worth noting that women who do resist the system, practices and injustices of prison life can face "uncompromising discipline, restraint and isolation" (Moore and Scraton, 2014: 9). In addition to negotiating these complex relationships there is a struggle against the numerous perceived injustices that appear to take place on a regular basis.

'The first week I came in, we were locked down that week because a knife or a pair of scissors had gone missing, so that was my first initial impact of prison, lockdown. All the power was turned off, there was no TV or anything, they obviously thought if we take that privilege away pressure would be put on the person who did it, because everyone was suffering. From 8 in the morning till 8 at night we had no power, some staff turned it back on at 6, some at 5. It was horrible' (Sam, 21, 4 years).

'You come into the prison they take hood coats off you, they take your jumps off you, I walked around for weeks in a tee shirt when I first came here, it was freezing' (Chanice, 25, 3 years).

It is difficult to plan and organise things for your release in any systematic way when such physical needs are not met. All this can have an impact on planning in a number of ways. The women feel more isolated and unsupported than they should. They do not on the whole feel able to turn to staff for 
help, whether that be in regards to resettlement or on a more personal issue. Without committed staff support there is little the women can practically achieve. The women's time and energy is spent negotiating the challenges of the day rather than focussing on what is coming tomorrow. One explanation given for some of the problems between staff and prisoner relations was the drain on resources and the staff shortages.

'Only 10 years ago you would have time on the wings to speak with them, you knew them, they knew you, they knew how far to go because you built up a rapport and a relationship. That is not happening now, everyone is so stressed, they have more work piled on them so they don't have that time. The rise in the population has impacted, but obviously staff shortages and the whole structure has changed' (Prison Officer- Tutor and Offender Supervisor). This is being further compounded by ever increasing cuts to prison staff (Hart and Schlembach, 2015).

\section{CONCLUSION}

The women in this prison, in this study face numerous barriers to overcome in order for them to be sufficiently prepared for release and to have successful resettlement and ultimately desist from future offending. They have personal barriers including family breakdown, turbulent relationships, chaotic histories characterised by abuse, childhoods spent in local authority care and drug and alcohol misuse. There are also structural barriers to surmount including housing concerns and homelessness, financial hardship, poor employment prospects and low educational achievement. Finally they have gendered barriers that they must transcend, particularly around motherhood and children, if they are to successfully desist.

The prison itself has proved detrimental to women's attempts to conquer these obstacles with the injustices of day-to-day prison life, the problem of institutionalisation and poor relationships with staff and consequently a breakdown in communication between staff and prisoners, only serving to make life even tougher for these women. The resettlement services themselves, while undertaking valuable work with some individuals, fail to engage with the women who are most in need due in part 
to the responsibilisation discourse. Despite these women being among the most marginalised in society, the evidence from this study shows a group of women who are motivated to change and live a crime free life on release. They have the desire to change if not the abilities or capital to achieve it. They are open to help and support and recognise the need for it. The staff view of the women is juxtaposed to this as they believe the women prisoners possess the capital and have the abilities needed to access support, but instead lack the motivation to change. These are women who have plans and aims for the future, plans not unlike those of the non-offending population involving a quiet life with their children, of being settled, healthy and free of drugs and the associated complications. They want a life without abuse where they have stable employment or are able to improve their level of education and their prospects.

The women are chronically lacking in all forms of capital that are needed for this process to successfully take place but also for long term desistance. They are lacking in cultural capital, as they do not have the skills to negotiate the prison resettlement system. They lack social capital due to the breakdown of family relationships and distance of the prison from family and friends. They have little legitimate symbolic capital on the outside as this has previously been attained through criminal behaviour among offending peer groups. Finally these women are without economic capital and financial hardship is a way of life. In addition, the current system is now one compounded by neoliberal cuts to services and constant restructuring.

When considering the situation of women offenders and the women prisoners in this study in particular, the numerous reforms surrounding resettlement and the reducing re-offending agenda as a whole, has aimed to improve the social and economic situations for many offenders on release from custody and reduce their chances of recidivism. However, this is done through the responsibilisation agenda which rewards those that 'help themselves' and resume a lifestyle that is compatible with dominant social norms. This leaves those without this ability and lacking in the necessary 'capital' further marginalised and increasingly socially excluded. In terms of resettlement practice in women's prisons these individuals are dropping through the resettlement net and being released with little hope of secondary desistance. In addition, it can be argued that the resettlement strategy is specifically 
gendered. Research has demonstrated that women prisoners have numerous gendered impediments and additional gendered structural inequalities with which to contend. There is no evidence from this research that these gendered inequalities are recognised by the prison or the resettlement services or indeed acted upon. Despite the recommendations of the Corston Report (Corston, 2007), there is little evidence that these clear, gendered structural barriers are being addressed in terms of resettlement. This study also demonstrates the failure by the prison to acknowledge that the women are motivated to change and consequently to view this as a resource that can be mobilised. It seems that the resettlement 'period' is unable to utilise or harness this motivation and it instead remains unexploited (as the re-offending rates demonstrate). What begins as motivation to change while inside prison soon becomes a return to the women's original life of struggling with substance misuse, mental health conditions, housing, employment and financial issues and continued involvement in the criminal justice system.

The responsibilisation strategy has led to the structural, gendered disadvantages that women offenders face being re framed as individual criminogenic need leading to these new forms of governance. This is instead of the recognition that these structural issues are in reality outside the individual control of offenders. There is acknowledgement in critical feminist scholarship that women's backgrounds and the nature of their differing needs determines their experiences of prison and the wider criminal justice system which is driven by male centred knowledge (Baldry, 2010). It is important to remember that differences between men and women go further than physicality and biology and encompass structural disadvantages that underpin women's lives generally and therefore ultimately shape the way they are disciplined and managed within prison and also post release (Carlton and Segrave, 2011).

Much research and scholarship has been dedicated to policy development and evaluation of services. However these gender focussed policies and practices have significant limitations. The development of women specific prison programmes, in particular the growth in cognitive motivational programmes that focus on the role agency and choice play in reducing re-offending rather than the external struggles faced (Carlen and Tombs, 2006), but also reforms to the women's estate itself and a focus on maintaining family ties and visitation, while important in improving the prisoners day to day lives, 
all deflect attention away from not only the failings of institutions but the structural, gendered inequalities experienced. In line with the argument by Hannah-Moffat et al. (2009) these measures emphasise offender responsibility and risk management in relation to re-offending and desistance and structure debates around individual pathology. The result is measures that create a façade of good practice and improvements in service provision which not only disguise discriminatory practices but also serve to maintain a system built on male centred assumptions, inequality and injustice.

It is difficult to see the impact of gender specific prison reforms that occur at a time of heightened women's prison populations and when public reports document not only discrimination but breaches of human rights within the prison system as a whole but also the women's estate. For example, an unannounced inspection revealed separation meetings, where women would say a final goodbye to their children who were being adopted away, were being undertaken in the public visitation hall. In addition a woman who had just arrived was held down and had her clothes cut off her when she refused to hand them over (HM Chief Inspector or Prisons, 2012). This move away from the recognition of structural barriers (both in terms of research and policy) and the re-framing of these issues as individual need operates against the backdrop of the wider neo liberal agenda and is being compounded by the on-going programme of austerity, cuts to staff, an elevated prison population, evidence of overcrowding and an increase in violent assaults and suicide within prisons (MoJ, 2014, 2014a; Howard League for Penal Reform, 2014). It is therefore hard to see how the women in this study would achieve their aims and turn their plans from intangible ideas into concrete packages of support and help but also how they would ever be able to exit the revolving door nature of the prison system and live the 'normal and quiet' life so many of them crave. It has never been more crucial given the current political and economic climate, for researchers to recognise the central role these (gendered) structural issues play in the desistance process and place them at the centre of future discussions. If women prisoners are to desist on release and form a stable and lasting non-offending life then these wider, gendered and structural complexities need to be addressed. 


\section{REFERENCES}

Arditti, J. A., \& Few, A., L. (2006). Mothers' reentry into family life following incarceration. Criminal Justice Policy, 17 (1) 103-123

Baldry, E. (2010). Women in transition from prison to...Current Issues in Criminal Justice (Special Issue on Women and Imprisonment) 22 (2).

Barry, M. (2007). The transitional pathways of young female offenders: towards a non-offending lifestyle. In R. Sheehan, G. McIvor and C. Trotter, eds. What Works with Women Offenders. Willan, Collumpton.

Barry, M. (2012). Young Women in Transition: From Offending to Desistance in F. Losel, A. Bottoms and D. Farrington. Young Adult Offenders. Lost in Translation? Willan, Collumpton.

Berman, J. (2005). Women offender transition and reentry: Gender responsive approaches to transitioning women offenders from prison to the community. Washington, DC: National Institute of Corrections.

Bourdieu, P. (1984). Distinction: A Social Critique of the Judgement of Taste. London: Routledge and Kegan Paul.

Bourdieu, P. (1986). The Forms of Capital. In J.G. Richardson (ed). Handbook of Theory and Research for the Sociology of Education. Westport, CT: Greenwood Press.

Brown, M. and Ross, S. (2010). Mentoring social capital and desistance: A study of women released from prison. Australian and New Zealand Journal of Criminology. 43 (1), P. 31.

Cabinet Office Social Exclusion Task Force (2009). Short Study on Women Offenders. London: Cabinet Office.

Caddle, D. and Crisp, D. (1997). Imprisoned women and mothers Home Office Research Study 162. London: Home Office. 
Carlen, P. and Tombs, J. (2006). Reconfigurations of Penality. The Ongoing Case of the Women's Imprisonment and Reintegration Industries. Theoretical Criminology. 10 (3), pp. 337-360.

Carlton, B.A and Segrave, M. T. (2011) Women's survival post-imprisonment: Connecting imprisonment with pains past and present. Punishment and Society. 13 (5), pp. 551-570.

Carlton, B.A., Segrave, M.T. (eds), (2013). Women exiting prison: critical essays on gender, postrelease support and survival, Routledge, London

Carlton, B.A. and Segrave, M.T. (2014). 'They died of a broken heart': Connecting women's experiences of trauma and criminalisation to survival and death post-imprisonment, The Howard Journal of Criminal Justice , 53 (3) pp. 270-289

Charmaz, K. (2014) Constructing Grounded Theory $2^{\text {nd }}$ edition, London: Sage

Cobbina, J. E. and Bender K. A. (2012) Predicting the Future: Incarcerated Women's Views of Reentry Success, Journal of Offender Rehabilitation, 51 (5) pp. 275-295

Cohen, S. (1985). Visions of Social Control- Crime, Punishment and Classification. Basil Blackwell: New York.

Corston, J. (2007). The Corston Report: A Report by Baroness Jean Corston of a Review of Women with Particular Vulnerabilities in the Criminal Justice System. London: Home Office.

Farrall, S. (2002). Rethinking What Works with Offenders: Probation, Social Context and Desistance from Crime. Willan: Cullompton.

Farrall, S. (2004). Social Capital and Offender Reintegration: Making probation desistance focussed. In S. Maruna and R. Immarigeon (eds), After Crime and Punishment: Pathways to Offender Reintegration. Collumpton: Willan.

Flood-Page, C., Campbell, S., Harrington, V. and Miller, J. (2000). Youth Crime: Findings from the 1998/99 Youth Lifestyles Survey, Home Office Research Study, 209, HMSO, London. 
Garland, D. (2001). The Culture of Control. Oxford: Oxford University Press.

Giordano, P. C, Cernkovich, S. A and Rudolph, J. L. (2002). Gender, Crime and Desistance: Toward a Theory of Cognitive Transformation. American Journal of Sociology. 107 (4), 990-1064.

Glaser, B.G. and Strauss, A.L. (1967). The Discovery of Grounded Theory. Chicago: Aldine Graham, J. and Bowling, B. (1995). Young People and Crime. London: HMSO.

Hannah-Moffat, K. (2001). Punishment in Disguise, Penal Governance and Federal Imprisonment of Women in Canada. University of Toronto Press: Toronto.

Hannah-Moffat, K., Maurutto, P and Turnbull, S. (2009) Negotiated risk: Actuarial illusions and discretion in probation. Canadian Journal of Law and Society 24 (3), 391-409.

Hart, E. L. (2014) Power, Pregnancy and Prison: The Impact of a Researcher's Pregnancy on Qualitative Interviews with Women Prisoners in K. Lumsden and A Winter, Reflexivity in Criminological Research, Basingstoke: Palgrave Macmillan.

Hart, E. L. and Schlembach, R. (2015) The Wrexham Titan prison and the case against prison expansion. Critical and Radical Social Work 3 (2), 289-294.

Herrschaft, B. A., Veysey, B. M., Tubman-Carbone, H. R., \& Christian, J. (2009). Gender differences in the transformation narrative: Implications for revised reentry strategies for female offenders. Journal of Offender Rehabilitation, 48 (6) 463-482

HM Chief Inspector of Prisons (2012) Report on an unannounced full follow-up inspection of HMP \& YOI New Hall, London: Her Majesty’s Inspectorate of Prisons Holtfreter, K. \& Wattanaporn, K. A. (2014). An examination of gender responsiveness for female offender reentry. Criminal Justice and Behavior, 41 (1) 41-57

Howard League for Penal Reform (2014). Breaking Point: Understaffing and Overcrowding in Prisons Research Briefing. Howard League for Penal Reform. 
Huebner, B.M., DeJung, C. and Cobbina, J.E. (2010). Women coming Home: Long term patterns of recidivism, Justice Quarterly. 27 (2) pp. 225-254

Kemshall, H. (2002). Effective Practice in Probation: An Example of 'Advanced Liberal Responsibilisation? Howard Journal of Criminal Justice. 41 (1) pp. 41-58.

Kreager, D.A., Matsueda, R.L. and Erosheva, E.A. (2010). Motherhood and Criminal desistance in disadvantaged neighborhoods. Criminology 48 (1) pp. 221-257

Leverentz, A.M. (2014) The Ex-Prisoner's Dilemma: How Women Negotiate Competing Narratives of Reentry and Desistance. New Brunswick, New Jersey: Rutgers University Press

Leverentz, A. M. (2006). 'The Love of a Good Man? Romantic Relationships as a Source of Support or Hindrance for Female Ex-Offenders'. Journal of Research in Crime and Delinquency. 43 (4), 459488.

MacRae, R., McIvor, G, Malloch, M, Marry, M and Murry, L. (2006). Evaluation of the Scottish Prison Service Transitional Care Initiative. Edinburgh: Scottish Executive.

Malin, S. (2004). Supporting People: Good News for Women Ex-Prisoners? Research Paper 2004/1, London: The Griffins Society.

Maruna, S. (2001). Making Good: How Ex-Convicts Reform and Rebuild their Lives. Washington D C: American Psychological Association.

McAdams, D.P. (1993). Stories we live by: Personal Myths and the Making of the Self. New York: Morrow.

McMahon, G. and Seemungal, F. (2003). The Employment and Educational Needs of Women Prisoners, Occasional Paper. Oxford: University of Oxford, Centre for Criminological Research and Probation Studies Unit.

Ministry of Justice (2013). Gender differences in substance misuse and mental health amongst prisoners. London: Ministry of Justice 
Ministry of Justice (2014). Offender Management Statistics Bulletin, England and Wales. Jan-March 2014. London: Ministry of Justice

Ministry of Justice (2014a). Safety in Custody Statistics England and Wales, Update to March 2014. London: Ministry of Justice.

Moore, L. and Scraton, P. (2014). The Incarceration of Women: Punishing Bodies, Breaking Spirits, Basingstoke: Palgrave Macmillan

National Offenders Management Service (2014). Prison Annual Performance Ratings 2013/14. National Offender Management Service.

Palmer, E., Hatcher, R., McGuire, J. and Hollin, C. (2015). Cognitive Skills Programs for Female Offenders in the Community, Effect on Reconviction. Criminal Justice and Behaviour, 42 (4) 345360

Prison Reform Trust (2010). Bromley Briefings Prison Fact file. December, 2010

Roberts, M. and Cobb, A. (2008). 'Mental health and detention'. Criminal Justice Matters. 71, pp.2627.

Rodderman, E, Kruttschnitt, C., Slotboom, A. and Bijleveld, C.C.J.H. (2016) Female desistance: A review of the literature. European Journal of Criminology. 13 (1) pp. 3-28

Rumgay, J. (2004). Scripts for Safer Survival: Pathways out of Female Crime. The Howard Journal. 43 (4), 405-419.

Schroeder, R., Giordano, P. and Cernkovich, S. (2010) Adult Child-parent Bonds and Life Course Criminality. Journal of Criminal Justice. 38, 562-571.

Scoular, J and O’Neill, M. (2007). 'Regulating Prostitution, Social Inclusion, Responsibilisation and the Politics of Prostitution Reform'. British Journal of Criminology. 47, 764-778. 
Scroggins, J. R., \& Malley, S. (2010). Reentry and the (unmet) needs of women. Journal of Offender Rehabilitation, 49 (2) 146-163

Sered, S. (2014) Suffering in an Age of Personal Responsibility, Contexts 13 (2) 38-43.

Social Exclusion Unit (2002). Reducing Reoffending by Ex Prisoners. London: Social Exclusion Unit Stewart, D. (2008). The Problems and Needs of Newly Sentenced Prisoners: results from a National Survey. London: Ministry of Justice.

Uggen, C. and Kruttschnitt, C. (1998). 'Crime in the Breaking: Gender Differences in Desistance'. Law and Society Review. 32 (2), 339-366.

Wahidin, A. (2004). Older Women in the Criminal Justice System: Running Out of Time. London: Jessica Kingsley.

http://www.bbc.co.uk/news/uk-28810439 accessed on 04/09/2015 